Vol. 3, No. 2 | July - December 2020

\title{
Current status of microalgae to produce biogas through pretreatment of lignocellulosic waste in the era of 21-Century
}

Ali Raza Ishaq ${ }^{1}$, Maleeha Manzoor ${ }^{2}$, Jawad Ahmad ${ }^{3}$, Qurat-ul-Ain Ahmad ${ }^{4}$, Fouzia Tabssum $^{5}$, Asma Chaudary ${ }^{4}$, Saif ur Rehman ${ }^{2}$, Tehreem Rafique ${ }^{6}$, Ayesha Noor ${ }^{2}$

\begin{abstract}
:
Modern day civilization is dependent on energy generation by fossil fuels. But the major drawback of using fossil fuels is environmental pollution. Microalgae are potential candidate for production of various products of interest, such as proteins, mini food, pigments and triglycerides that can be converted into biofuels. Lignocellulosic feedstocks are the most abundantly available raw material of plants that can serve as a promising feedstock for cultivating bacteria, fungi, yeast and microalgae to produce biofuels and other value-added products. Owing to the abundant availability of these low/no cost substrates, can be utilized as feedstocks for cultivating microalgae to generate biogas/biodiesel. Likewise, there is much room to exploit defatted algal biomass to be used as animal/fish feed and oil producing/accumulating genes knowledge in future to produce high and good quality biodiesel and biogas.
\end{abstract}

Keywords: Lignocellulosic Substrate; Pre-Treatment; Microalgae/Cyanobacteria; Biogas; Problems; Animal Feed

\section{Introduction}

Now-a-days energy resources are inadequate in numbers for desirable production of energy with less frugal resources [1]. Energy and environmental pollution are included in the top ten problems of the world. The desirable amount of oil and other energy products are reduced, and energy requirements reach at elevated point in this modern era. According to World Trend Plus's
Association: Energy Sector in Pakistan, oil consumption was reported at 498.197 barrel/day in 2018 and oil demand is about to increase upto $60 \%$. Fossil fuels are nonrenewable resources that are eradicated rapidly and can cause drastic effect on economic cost of any developing country [2, $3]$. The depletion of fossil fuel is affecting certain environmental conditions such as abiotic factors like temperature, climate,

\footnotetext{
${ }^{1}$ State Key Laboratory of Biocatalysis and Enzyme Engineering, Environmental Microbial

Technology Center of Hubei, College of Life Science, Hubei University, Wuhan 430062 China

${ }^{2}$ Department of Zoology, Government College University Faisalabad Punjab Pakistan

${ }^{3}$ Department of Mechanical Engineering, University of Engineering \& Technology, Lahore

${ }^{4}$ Division of Science, University of Education, Lahore

${ }^{5}$ Department of Zoology, University of Education, Lahore

${ }^{6}$ Department of Ecology and environmental science, East China Normal University

Corresponding author: maleehamanzoor@gcuf.edu.pk
} 
Ali Raza (et al.), Current status of microalgae to produce biogas through pretreatment of lignocellulosic waste in the era of 21-Century

greenhouse effect [4] and ultra-violet radiation $[5,6]$.

It is reported earlier that Chinese people used microalgae (Nostoc sp.) to overcome the famine condition about 2000 year ago [7]. Biomass mainly consisted of compost and manure which may be terrestrial and aquatic [8]. Biomass feedstock is a renewable source of energy for the output of biogas [9] and biofuel through anaerobic microalgal digestion [10] as show in Fig, 1.

Terrestrial biomass is a promising agent to produce renewable energy whereas, aquatic biomass is easily available to be produce energy at large scale without causing any environmental hazards and economically feasible too [8]. The most promising way to obtain maximum energy with less economic cost is decomposition of biomass by using microalgae [11, 12]. Algae is unicellular and simple multicellular organisms with photosynthetic pigments such as chlorophyll $\mathrm{a}, \mathrm{b}, \mathrm{c}$ and other accessory pigments. There are several globally dominating species of

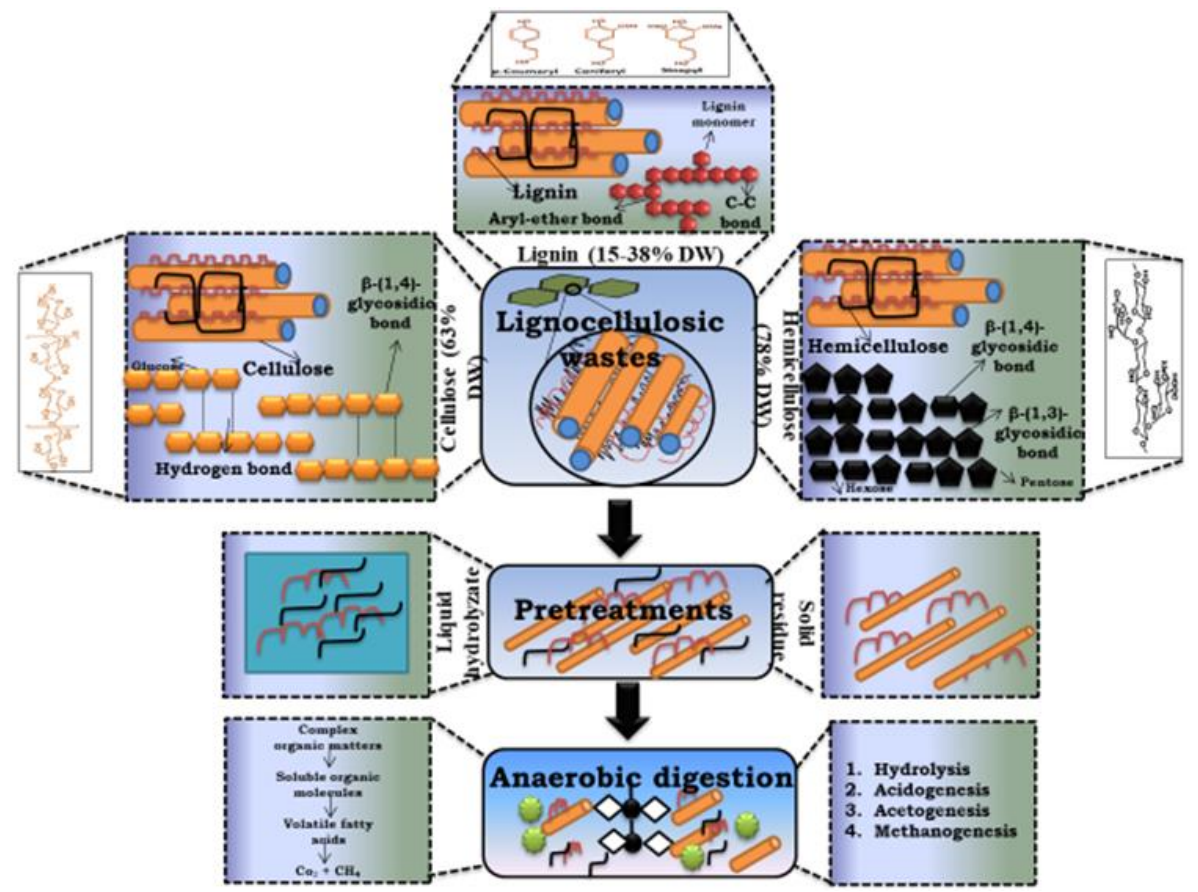

Fig 1:Overview microalgal bio-energy products through pre-treatment of Lignocellulosic wastes 
Ali Raza (et al.), Current status of microalgae to produce biogas through pretreatment of lignocellulosic waste in the era of 21-Century

Table I Advantages of using microalgae/cyanobacteria for biogas production

\begin{tabular}{|c|c|c|}
\hline Sr No & $\begin{array}{l}\text { Advantages of using microalgae/cyanobacteria for } \\
\text { biogas production }\end{array}$ & References \\
\hline 01 & $\begin{array}{l}\text { Microalgae/cyanobacteria can grow at high levels of } \\
\mathrm{CO}_{2} \text { throughout year }\end{array}$ & {$[12,14]$} \\
\hline 02 & $\begin{array}{l}\text { Microalgae/cyanobacteria can grow in } \\
\text { marine/brackish, freshwater and wastewaters thus less } \\
\text { competition for arable land }\end{array}$ & {$[15][40[16][17,18]]$} \\
\hline 03 & $\begin{array}{l}\text { Microalgal biomass is a rich source of other co- } \\
\text { products such as gasoline and biohydrogen etc. }\end{array}$ & [17] \\
\hline 04 & $\begin{array}{l}\text { Microalgae/cyanobacteria are ubiquitous and serves } \\
\text { as a promising candidate to generate high rates of } \\
\text { productivity }\end{array}$ & {$[5,16]$} \\
\hline 05 & $\begin{array}{l}\text { They play important role in oxygen production. } \\
\text { nitrogen cycle and reformed the oxidizing } \\
\text { environment from reducing environment. }\end{array}$ & \\
\hline 06 & $\begin{array}{l}\text { The requirements for nourishing the } \\
\text { microalgae/cyanobacteria is very simple and } \\
\text { prosperous agent to convert the solar energy into } \mathrm{CO}_{2} \text {, } \\
\text { also originator of various feedstock for energy } \\
\text { producing compound such as lipids, carbohydrates } \\
\text { and protein. }\end{array}$ & \\
\hline
\end{tabular}

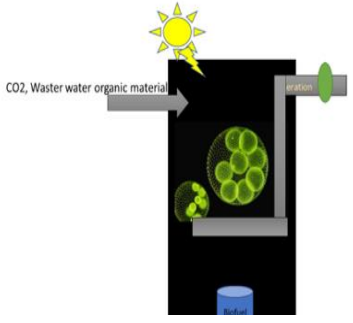

Fig 2: Basic Structure of Photobioreactor

\section{Lignocellulosic waste}

Food and plant-based waste known as lignocellulosic waste is produced up to 1.3 billion ton/year around the world [23]. Lignocellulose waste is an inexpensive and renewable energy source to produce high yield of biomass approximately 50\% [24] and helps in carbon dioxide sequestration [25] globally throughout the year. Lignocellulose is mainly composed of hemicellulose, lignin, cellulose, phenolics [26] and other inorganic materials [27], their rate of production totally depends on plant species [28]. Major lignocellulosic biomass resources are manure, woodlot arising, crop residues, agroindustrial wastes, sugarcane, bagasse, sawdust and consecrated energy crop Table II.

\subsection{Cellulose:}

Cellulose is most abundant polysaccharide in biosphere and chief ingredient of higher plants, brown, red and green algae. Cellulose is unbranched polymer, formed by monomer of glucose that are linked by $\beta$ - 1,4- glycosidic bond. Its degree of polymerization is about to 14000 15000 glucose monomer each monomer rotates at $180 \mathrm{o}$ angle. 
Ali Raza (et al.), Current status of microalgae to produce biogas through pretreatment of lignocellulosic waste in the era of 21-Century

Table II Major lignocellulosic wastes and their composition

\begin{tabular}{|c|c|c|c|c|c|}
\hline $\begin{array}{l}\text { Sr } \\
\text { NO: }\end{array}$ & $\begin{array}{l}\text { Lignocellulose } \\
\text { wastes }\end{array}$ & $\begin{array}{l}\text { Cellulose } \\
\text { (wt \%) }\end{array}$ & $\begin{array}{l}\text { Hemicellulose } \\
\text { (wt \%) }\end{array}$ & $\begin{array}{l}\text { Lignin } \\
\text { (wt \%) }\end{array}$ & References \\
\hline 01 & Corn stalks & 35.0 & 16.8 & 7.0 & \multirow[t]{3}{*}{ [29] } \\
\hline 02 & Sugarcane bagasse & 40.0 & 27.0 & 10.0 & \\
\hline 03 & Wheat straw & 32.9 & 24.0 & 8.9 & \\
\hline 04 & $\begin{array}{l}\text { Soft wood } \\
\text { (spruce) }\end{array}$ & 44.7 & 22.9 & 30.6 & \multirow[t]{3}{*}{ [30] } \\
\hline 05 & $\begin{array}{l}\text { Hard wood } \\
\text { (beech) }\end{array}$ & 45.6 & 25.9 & 23.8 & \\
\hline 06 & Grass (switch grass) & $32.2 \%$ & $24.4 \%$ & $23.3 \%$ & \\
\hline
\end{tabular}

\subsection{Hemicellulose}

The second most important polymer in this biosphere is hemicellulose which has random and amorphous structure, consisted of heteropolymer such as xyloglucan, glucomannan, arabinoxylan, glucuronoxylan, galactomannan and xylans [31]. Due to this, its chemical composition deviated from species to species, however, xylans and glucomannan are present in hard wood or soft wood respectively[31]. Hemicellulose makes up $15-35 \%$ plant biomass that are joined with cellulose by hydrogen bond, to lignin through covalent bond

\subsection{Lignin}

Lignin are large, complex and crosslinked aromatic polymers that are formed by oxidative combinative conjugation of 4hydroxy-phenyl-porpanoids [32]. Lignin monomers are linked together through $\mathrm{C}-\mathrm{C}$ and aryl ether linkage associating with varieties of functional group such as methoxy, phenolic hydroxy and adjacent aldehyde [33]. Divergence in composition of bond and functional group depend on the plant's species biomass. Lignin provide strength and protect from stress condition by association with cellulose and hemicellulose.

\section{Pre-treatment of lignocellulosic waste:}

Pre-treatment is a critical procedure for the biochemical renovation of lignocellulosic biomass into bioethanol, biogas, biohydrogen [34]. This process is essential to modify the cellulosic biomass for making large quantity of cellulose which is converted into the carbohydrate polymers (fermentable sugars) by the action of specific enzymes [35]. Pretreatment of lignocellulosic wastes is completed through the acidic, basic and enzymatic courses [36]. Recent research reveals that enzymatic hydrolysis is bestidentified technique to get high yield of biomass Fig, 3.

\subsection{Acidic Hydrolysis}

Acidic method is one of the efficient methods to treat the lignocellulosic wastes through weak or strong acid hydrolysis specifically dilute acid hydrolysis that is most effective to gain high yield of biogas [28] . There are two types of weak acid hydrolysis usually:

- Extreme temperature for low solids loading (T> $160{ }^{\circ} \mathrm{C}, \quad 5-10 \quad$ wt $\%$ substrate concentration). 
Ali Raza (et al.), Current status of microalgae to produce biogas through pretreatment of lignocellulosic waste in the era of 21-Century

- Low temperature for high solids loading $\left(\mathrm{T} \leq 160{ }^{\circ} \mathrm{C}, 10-40 \%\right.$ substrate concentration).

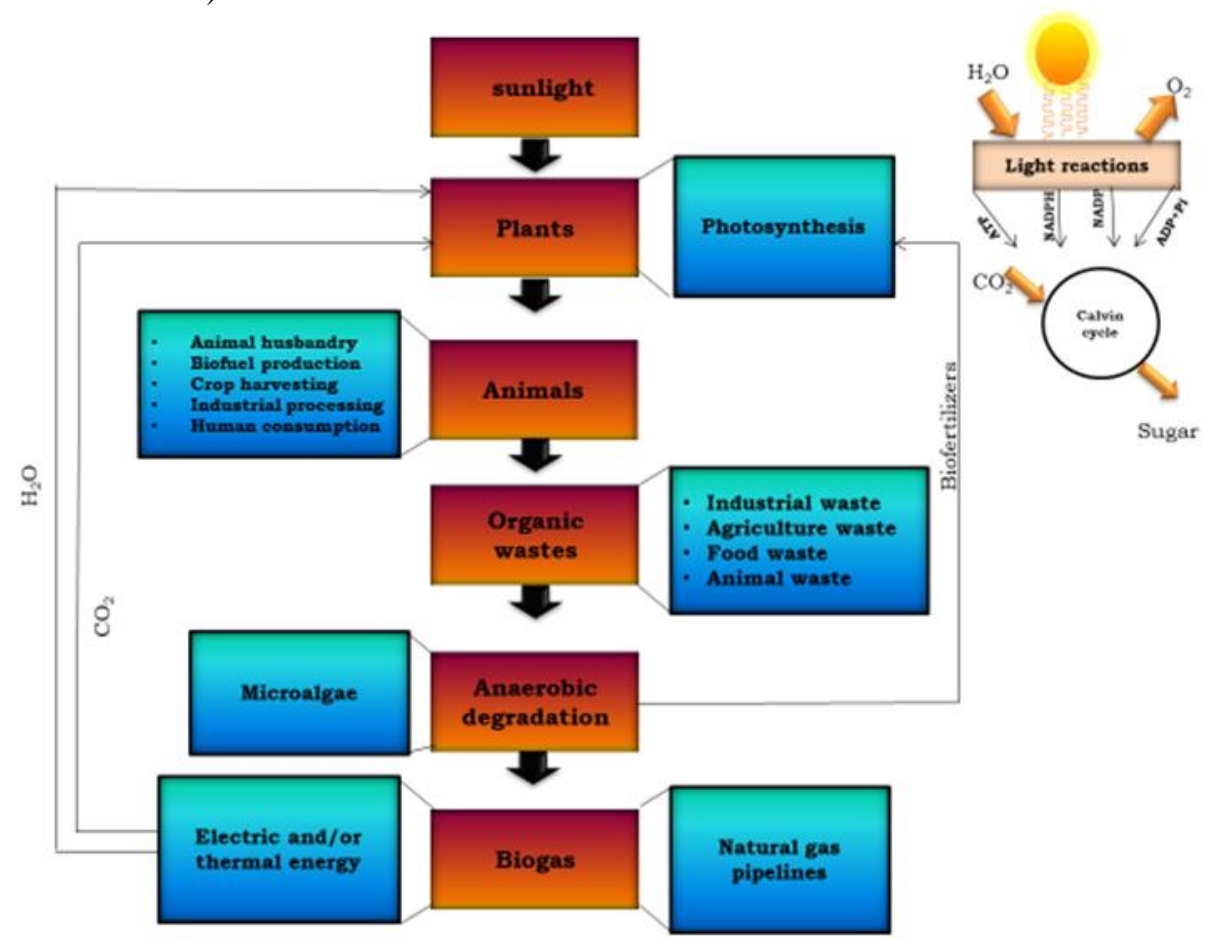

Fig, 3. Schematic representation of pre-treatment of lignocellulosic biomass procedure

Dilute $\mathrm{H} 2 \mathrm{SO} 4$ is most used acid for hydrolysis at $160-220{ }^{\circ} \mathrm{C}$ for few minutes. Organic acids such as maleic acid, fumaric acid can also be used for dilute acid pre-treatment. The hydrolysate produced is a mixture of various valuable organic carbon, in the form of sugars and acts as a potential source to support microalgal growth and production of other targeted compounds such as oil and pigments [26].

Treatment of lignocellulosic waste with concentrated strong acids such as $\mathrm{H} 2 \mathrm{SO} 4$ and $\mathrm{HCl}$ have been extensively used since they are powerful agents for cellulose hydrolysis with less enzyme requirement. Some advantages of using concentrated acid hydrolysis are high monomeric sugar yield as well as slight temperature conditions are required. The most common drawback is alteration of natural cycles (Carbon, Nitrogen and water cycle).

\subsection{Alkaline Method}

Three bases are commonly used in lignocellulosic pre-treatment for generation of high energy amalgams such as biogas, biohydrogen and methane etc.

\section{i. Calcium Hydroxide \\ ii. Sodium Hydroxide \\ iii. Ammonia}

Lignocellulosic biomass must be discoloured through microbial enzymes which perform output chemical hydrolysis because enzymes demonstrate the high substrate and reaction specificity, activate beneath minor circumstances and not produce by-products [49]. Due to this enzymatic method is precious for chemical, fuel, food and textile industries as well as in washing powder constructions and in paper making Table III. 
Ali Raza (et al.), Current status of microalgae to produce biogas through pretreatment of lignocellulosic waste in the era of 21-Century

Table III Effect of Biogas production through various Pre-treatment methods

\begin{tabular}{|c|c|c|c|c|c|}
\hline $\begin{array}{l}\text { Sr. } \\
\text { No }\end{array}$ & $\begin{array}{l}\text { Pre- } \\
\text { treatment } \\
\text { method }\end{array}$ & $\begin{array}{l}\text { Enhancement } \\
\text { of Biogas \% }\end{array}$ & Advantage & Disadvantage & References \\
\hline 01 & Acidic & $0-166$ & $\begin{array}{l}\text { Destruction } \\
\text { of lignin and } \\
\text { hemicellulose }\end{array}$ & $\begin{array}{ll}\text { - } & \begin{array}{l}\text { High charge } \\
\text { of acid }\end{array} \\
\text { - } & \begin{array}{l}\text { Deterioration } \\
\text { problem }\end{array} \\
\text { in digester } \\
\text { - } & \begin{array}{l}\text { Establishment } \\
\text { of inhibitory } \\
\text { substance }\end{array} \\
\end{array}$ & [37] \\
\hline 02 & Basic & $0-207$ & $\begin{array}{l}\text { Solubilizes } \\
\text { the lignin and } \\
\text { hemicellulose }\end{array}$ & $\begin{array}{ll}\text { - } & \text { High alkali } \\
\text { meditation in } \\
\text { digester } \\
\text { - } \\
\text { Elevated cost } \\
\text { of chemical }\end{array}$ & \\
\hline 03 & Enzymatic & $0-208$ & $\begin{array}{l}\text { Low energy } \\
\text { feasting }\end{array}$ & $\begin{array}{ll}\text { - } & \text { Unceasing } \\
\text { adding } \\
\text { mandatory } \\
\text { - } \\
\text { High cost of } \\
\text { enzymes }\end{array}$ & [38] \\
\hline
\end{tabular}

\section{Wastes water Treatment}

In any developing country, quantity of wastewater production every day is gigantic because of growing population and swift industrialization. Due to this, water pollution is one of the greatest life-threatening environmental problem [18, 39]. Countless number of methods are adopted for treating the wastewater that cause pollution in environment, all of these are not economically feasible but one of the best methods for treating wastewater by microalgae that is economical and eco-friendly too. This method is also known as microalgae-based wastewater treatment (MBWT)[40]. One of advantages of using microalgae based wastewater treatment is that they have capability to remove heavy metals, inorganic ions and other organic material [16]. Following types of wastewater are being treated by cultivating microalgae.

1. Sewage wastewater

2. Municipal Wastewater

3. Industrial wastewater

Both quantitative and qualitative characteristics of lipids content in algal biomass fluctuate due to variable growth conditions such as temperature, $\mathrm{pH}$, light intensity and nutrition media (concentration of nitrogen, iron, phosphate and other inorganic molecules) $[10,21]$. The microalgae cultivation is also effected by some other biotic factors such as pathogens and presence or absence of other algal species [41]. Biomass treatment is depending on environmental conditions which influence the production of biogas. Biogas and methane productivities is directly linked to conditions which is provided, 
Ali Raza (et al.), Current status of microalgae to produce biogas through pretreatment of lignocellulosic waste in the era of 21-Century

suitable condition gives us high level of biogas

as shown in Table IV.

Table IV Methane and biogas yield of some microalgae species by using wastewater

\begin{tabular}{|c|c|c|c|c|c|c|}
\hline Species & $\begin{array}{l}\text { Optimum } \\
\text { Temperatu } \\
\text { re }\end{array}$ & $\begin{array}{l}\text { Reactor } \\
\text { type }\end{array}$ & $\begin{array}{l}\text { Type of } \\
\text { Waste(s)/ } \\
\text { Water }\end{array}$ & $\begin{array}{l}\text { Metha } \\
\text { ne (L } \\
\mathrm{CH}_{4} \\
\text { g/VS) }\end{array}$ & $\begin{array}{l}\text { Biogas } \\
\text { Yield } \\
(\mathrm{ml} / \mathrm{gVS} \\
\text { ) }\end{array}$ & $\begin{array}{l}\text { Referenc } \\
\text { es }\end{array}$ \\
\hline $\begin{array}{l}\text { Spirulina } \\
\text { platensis }\end{array}$ & 30 & $\begin{array}{l}\text { CSRT/Se } \\
\text { mi } \\
\text { continuou } \\
\text { s/ Batch }\end{array}$ & $\begin{array}{l}\text { Sewage } \\
\text { Sludge }\end{array}$ & $\begin{array}{l}0.26- \\
0.32\end{array}$ & $\begin{array}{l}525-640 \\
\mathrm{ml} / \mathrm{gVS}\end{array}$ & [42] \\
\hline $\begin{array}{l}\text { Chlorella } \\
\text { vulgaris }\end{array}$ & $28-31$ & Batch & $\begin{array}{l}\text { Domestic } \\
\text { and } \\
\text { Municipal } \\
\text { wastewate } \\
\mathrm{r}\end{array}$ & $\begin{array}{l}0.31- \\
0.35\end{array}$ & $\begin{array}{l}238-99 \\
\mathrm{ml} / \mathrm{gVS}\end{array}$ & [43] \\
\hline Chlorella sp. & 35 & Batch & $\begin{array}{l}\text { Seafood } \\
\text { Processin } \\
\mathrm{g}\end{array}$ & $\begin{array}{l}0.17- \\
0.32\end{array}$ & $\begin{array}{l}44 \quad \mathrm{ml} \\
\mathrm{CH}_{4} / \mathrm{gV} \\
\mathrm{S} \quad \text { (from } \\
\text { chlorella } \\
\text { sp.) } \\
193 \mathrm{ml} \\
\mathrm{CH}_{4} / \mathrm{gV} \\
\mathrm{S} \quad \text { from } \\
\text { processi } \\
\text { ng of } \\
\text { Seafood }\end{array}$ & [44] \\
\hline $\begin{array}{l}\text { Scenedesmus } \\
\text { obliquus }\end{array}$ & $35-37$ & Batch & $\begin{array}{l}\text { Secondar } \\
\text { y waste } \\
\text { effluents } \\
\text { and } \\
\text { Municipal } \\
\text { wastewate } \\
\text { r, urban } \\
\text { wastewate } \\
\text { r }\end{array}$ & 0.18 & $\begin{array}{l}346 \quad \mathrm{~L} \\
\mathrm{CH}_{4} / \mathrm{Kg} \\
\mathrm{VS} \\
287 \\
\mathrm{ml} / \mathrm{gVS}\end{array}$ & [45-47] \\
\hline $\begin{array}{l}\text { Chlamydomon } \\
\text { as reinhardtii }\end{array}$ & 38 & Batch & $\begin{array}{l}\text { Wastewat } \\
\text { er at } \\
\text { different } \\
\text { level of } \\
\text { treatment }\end{array}$ & 0.39 & $\begin{array}{l}587 \\
\mathrm{ml} / \mathrm{gVS}\end{array}$ & {$[39,46]$} \\
\hline $\begin{array}{l}\text { Botrycoccus } \\
\text { braunii }\end{array}$ & 35 & Batch & $\begin{array}{l}\text { Secondar } \\
\text { y treated } \\
\text { sewage } \\
\text { from } \\
\text { domestic }\end{array}$ & $\begin{array}{l}404 \\
\mathrm{~mL} / \mathrm{CH} \\
4 \mathrm{~g} \mathrm{VS}\end{array}$ & $\begin{array}{l}614.11 \\
\mathrm{~L} / \mathrm{kg}\end{array}$ & $\begin{array}{l}{[48,49]} \\
{[50]}\end{array}$ \\
\hline
\end{tabular}

SJET | ISSN: 2616-7069 | Vol. 3 | No. 2 | 1052020 Sukkur IBA University 
Ali Raza (et al.), Current status of microalgae to produce biogas through pretreatment of lignocellulosic waste in the era of 21-Century

\begin{tabular}{|l|l|l|l|l|l|l|}
\hline & & & $\begin{array}{l}\text { wastewate } \\
\text { r, Red } \\
\text { Nile } \\
\text { Tilapia } \\
\text { Effluent }\end{array}$ & & & \\
\hline $\begin{array}{l}\text { Spirulina } \\
\text { maxima }\end{array}$ & 35 & Batch & & 330 & $\begin{array}{l}361-382 \\
\text { L/Kg VS }\end{array}$ & [51] \\
\hline Tetraselmis sp & 35 & Batch & $\begin{array}{l}\text { Urban } \\
\text { wastewate } \\
\text { r } \\
\text { treatment }\end{array}$ & 420 & $\begin{array}{l}\text { 419-431 } \\
\text { L/Kg VS }\end{array}$ & [52] \\
& & & & & \\
\hline
\end{tabular}

\subsection{Effect of temperature}

The effect of temperature on microalgae growth display significant role [53]. Researchers found that optimal temperature for microalgal growth is $20-30 \mathrm{oC}$ although they can also grow in constant temperature. Microalgae showed less growth when temperature is $160 \mathrm{C}$ but showed increased growth rate as temperature increase up to $28 \pm 30 \mathrm{oC}$. The microalgal growth rate is affected at $30 \mathrm{oC}$, decreased at $32 \mathrm{oC}$ and almost $17 \%$ decline growth rate at $35 \mathrm{oC}$ [54]. When temperature is above the optimal temperature about $38 \mathrm{oC}$ that led to death of algal cell biomass due to denaturation of protein $[55,56]$.

\subsection{Effect of $\mathbf{p H}$}

Microalgae grow in variable ranges of $\mathrm{pH}$ but the optimal $\mathrm{pH}$ for microalgae is $7-8$ to show have maximum growth rate [48]. It is also observed that growth must be influenced by different ranges of $\mathrm{pH}$ such as at $6.5 \mathrm{pH}$ growth rate is low but at 7-8 $\mathrm{pH}$ showed fastest growth rate [57]. When $\mathrm{pH}$ is above optimal range for example 9 than there is continuous decline in growth rate. It is also found that $\mathrm{pH}$ should be maintained at optimum range to sustain the growth of microalgae. That's why $\mathrm{pH}$ is estimated to be third most important factor (after temperature and light intensity) for microalgae growth [54, $58,59]$.

\subsection{Effect of light}

Diverse form of lights coming from different sources can be categorized as direct sunlight, indirect sunlight, fluorescent light and under dark, effect the growth rate of microalgae [27, 60]. Under dark conditions, microalgae growth is not documented since light is crucial constituent for their growth and microalgal culture is set near to the window to have direct sunlight [61]. In case of direct sunlight, microalgae give maximum rate of growth specifically if fluorescent light is provided. Microalgae growth is also dependant on light intensity, exposure and penetration thus, high light intensity damages the composition of pigments (phycobilin and phycoerythrin their nature different from other plant pigments based on molecular structure and absorption of light) and affects microalgal growth rate $[27,53,60]$.

\subsection{Effect of Aeration}

Continuous aeration is an essential factor for cultivating unicellular form of algae (Chlorella sp.). Thus, without any mean of aeration, no growth is recorded due to death of microalgae biomass cell. Various modes for aeration are in use in a photobioreactor for better growth and enhanced amount algal fuel [62]. 
Ali Raza (et al.), Current status of microalgae to produce biogas through pretreatment of lignocellulosic waste in the era of 21-Century

(pp. 99 - 114)

\section{Inhibitors as by - Product of Lignocellulosic waste treatment}

Inhibitors are those compounds which can stop or slow a biochemical process that may be competitive or non-competitive inhibitors. The by-product of pretreatment depends on the nature of chemical reaction and type of method which we use. Inhibitors can stunt the growth of microorganism such as phenolic compound, aromatics, aliphatic acid, furan aldehydes, inorganic ions and other bioalcohols [63-65].

\subsection{Phenolic Compound}

We draw out phenolic compound during the pretreatment of lignin and wood extractives. Phenolic compounds are longfamiliar with inhibiting activity against microorganism due to various strains of microalgae show the various responses against these types of compounds. Some microalgae/cyanobacteria show complete resistant against phenolic compounds such as Chlorella saccharophila, Scenedesmus quadricauda, Chlorella zofingiensis, Coelastrum microporum and Mesotaenium caldarorium [26].

\subsection{Furans}

Furans are union of furfural and Hydroxymethyl furfurals (HMF) produced during the pretreatment of sugar and lignocellulosic waste with acids or base [66]. Knowledge about the effect of furans on microalgae growth is scarce but a certain amount of furfural and HMF stimulate the inhibition of growth and ethanol production in diverse species of microalgae such as Saccharomyces cerevisiae, Zymomonas mobilis, Pichia stipites and Candida shehatae.

\subsection{Levulinic Acid}

Levulinic acid is produced by the decomposition of $\mathrm{HMF}$ and $1.16 \mathrm{~g} / \mathrm{L}$ of levulinic acid can stunt the growth of microalgae i.e Sceletonema costatum, Chlorella vulgaris and Agmenellum quadruplicatum [66].

\subsection{Fatty acid}

Fatty acids are powerful part of lignocellulose waste material that are constitutent of wood of various trees such as Eucalyptus. Fatty acids also act as inhibitory agent in various species but their peculiar types such as oleic acid, palmitic acid and linoleic acids have pronounced inhibitory effect on many microalgae species such as S. capricornutum, Monoraphidium contortum and Chlorella vulgaris [26].

\section{Biogas productivities}

Microalgal species required specific medium for their growth or normal functioning on the substrate to produce large quantity of biogas yield/productivity [17, 67]. These are also helpful for treating the agroindustrial wastes help reducing the environmental pollution Table V.

\section{Problems associated with anaerobic digestion of microalgae}

Anaerobic digestion is not best known or beneficial method because a lot of complications faced while dealing with microalgae by cultivating on agro-industrial wastes [46]. Some of the challenges are:

Low concentration of digestible substrate

Microalgae biomass is unique substrate for gaining high energy foodstuffs with lower commercial rate or low economically rate. Micro-algae with low volatile solid piling quantity can be utilized as digestible substrate for extraction of less concentrated biomass [57].

\subsection{Cell wall degradability}

Cell wall degradability is major problem for anaerobic digestion because its rigidity effect the biogas productivity due to incomplete breakdown of cell wall $[15,57]$. Impregnation of carbohydrates and supplementary biomolecules make the cell wall more rigid. Thus, biogas productivity from microalgae depends on the rigidity of cell wall [52]. Cell wall provide protection to inner organic matter of microalgae from bacterial infection. Bacteria can easily grow 
Ali Raza (et al.), Current status of microalgae to produce biogas through pretreatment of lignocellulosic waste in the era of 21-Century

and proceed anaerobic digestion after

breaking down of microalgal cell wall. [46]

Fig, 4.

Table V Microalgal Biogas Yield and Biogas productivity

\begin{tabular}{|c|c|c|c|c|}
\hline $\begin{array}{l}\text { Sr. } \\
\text { No }\end{array}$ & Microalgae & $\begin{array}{ll}\text { Biogas } & \text { yield } \\
\text { ml/g DM } & \end{array}$ & $\begin{array}{l}\text { Biogas } \\
\text { Productivity (P) } \\
\text { ml/1V }\end{array}$ & References \\
\hline 01 & Desmodesmus.sp & 456 & 1436.40 & \multirow[t]{8}{*}{ [12] } \\
\hline 02 & D. armatus & 440 & 1318.53 & \\
\hline 03 & H. pluvialis & 413 & 1261.63 & \\
\hline 04 & S. obliqus & 433 & 548.47 & \\
\hline 05 & C. vulgaris & 510 & 1944.80 & \\
\hline 06 & C. sacharophilum & 303 & 887.79 & \\
\hline 07 & Geminella.sp. & 448 & 981.12 & \\
\hline 08 & G. terricola & 316 & 449.77 & \\
\hline 09 & P. tricornutum & $0.337 \mathrm{~L}$ & $=$ & \multirow[t]{2}{*}[15]{} \\
\hline 10 & Isochrysis galbana & $0.22 \mathrm{~L}$ & & \\
\hline 11 & Scenedesmus sp. & 646 & & \multirow[t]{2}{*}{ [68] } \\
\hline 12 & Chlorella sp. & 652 & & \\
\hline 13 & Cladophora glomerate & $0.20 \mathrm{~m}^{3} / \mathrm{m}^{3} \mathrm{~d}$ & & \multirow[t]{3}{*}{ [9] } \\
\hline 14 & Chara fragilis & $0.12 \mathrm{~m}^{3} / \mathrm{m}^{3} \mathrm{~d}$ & & \\
\hline 15 & Spirogyra neglecta & $0.23 \mathrm{~m}^{3} / \mathrm{m}^{3} \mathrm{~d}$ & & \\
\hline
\end{tabular}

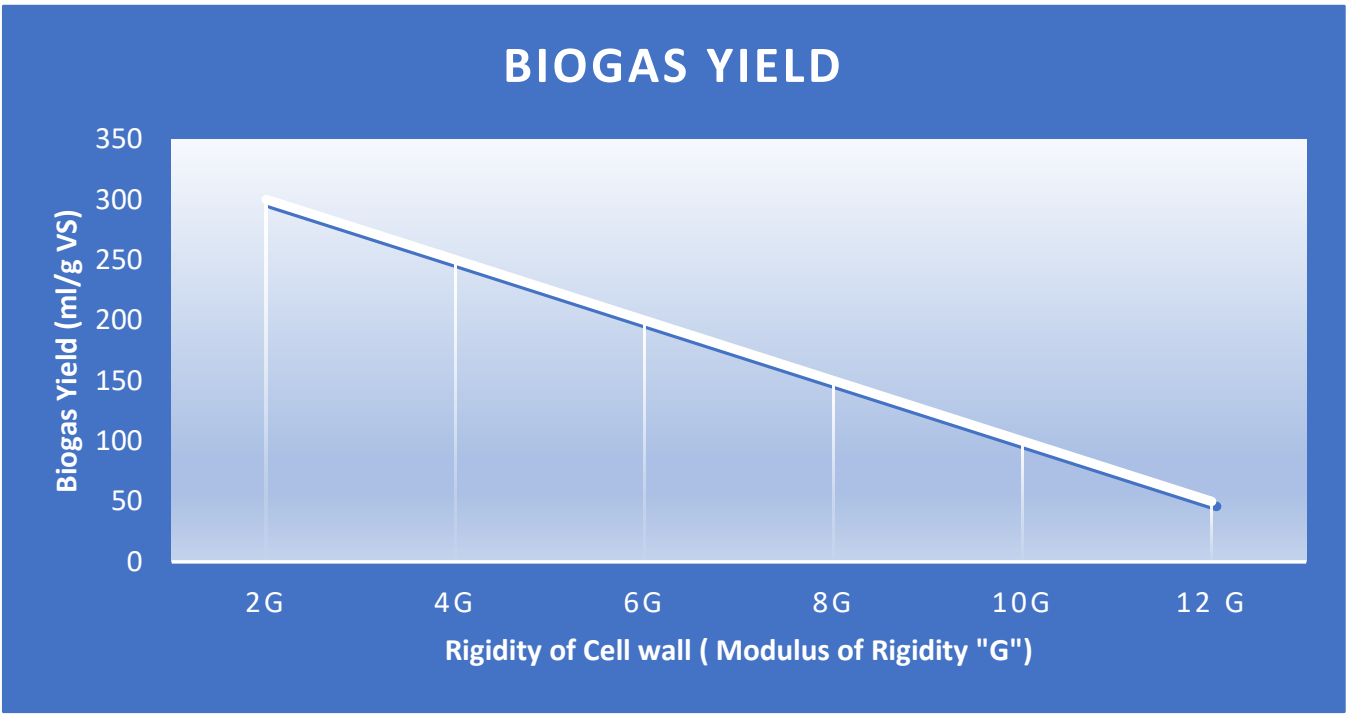

Fig, 4. Rigidity of cell wall in terms of Modulus of Rigidity) Between Biogas yield (ml/g VS along $\mathrm{Y}$ - axis) and Microalgal cell wall rigidity (Modulus of Rigidity $(\mathrm{G})$ along $\mathrm{X}$ - axis. 
Ali Raza (et al.), Current status of microalgae to produce biogas through pretreatment of lignocellulosic waste in the era of 21-Century (pp. 1 - 24)

Solubilization and surface area effect the organic matter [34, 69]. The solution for this production of biogas by bacteria on inner problem is shown in Fig, 5.

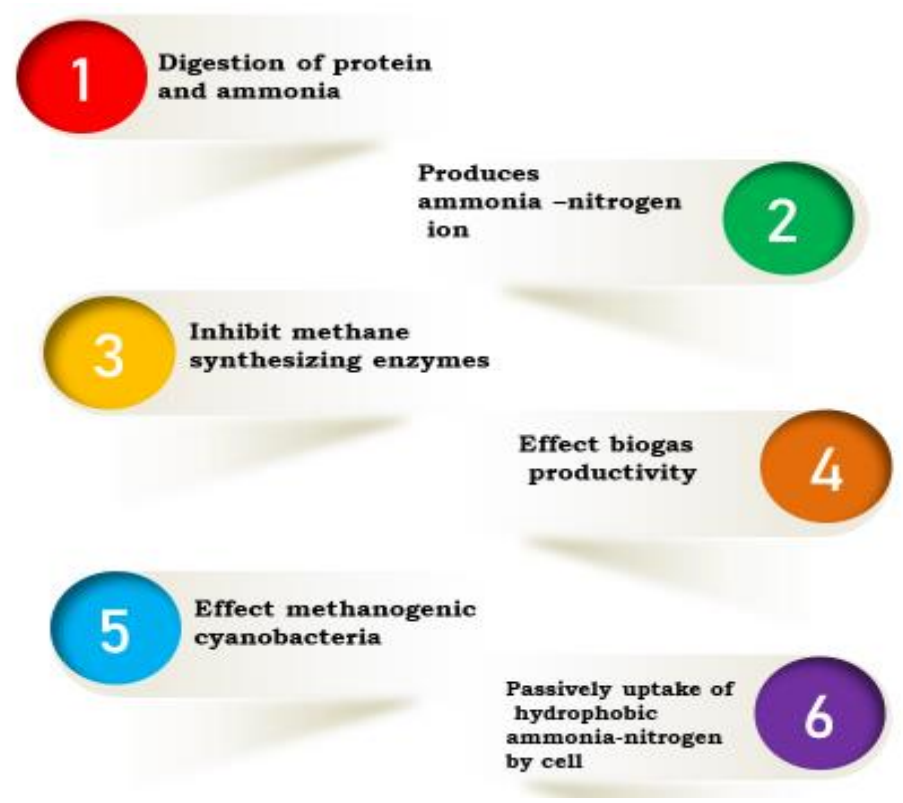

Fig, 5. Solution of Cell wall rigidity for enhancing Biogas Production

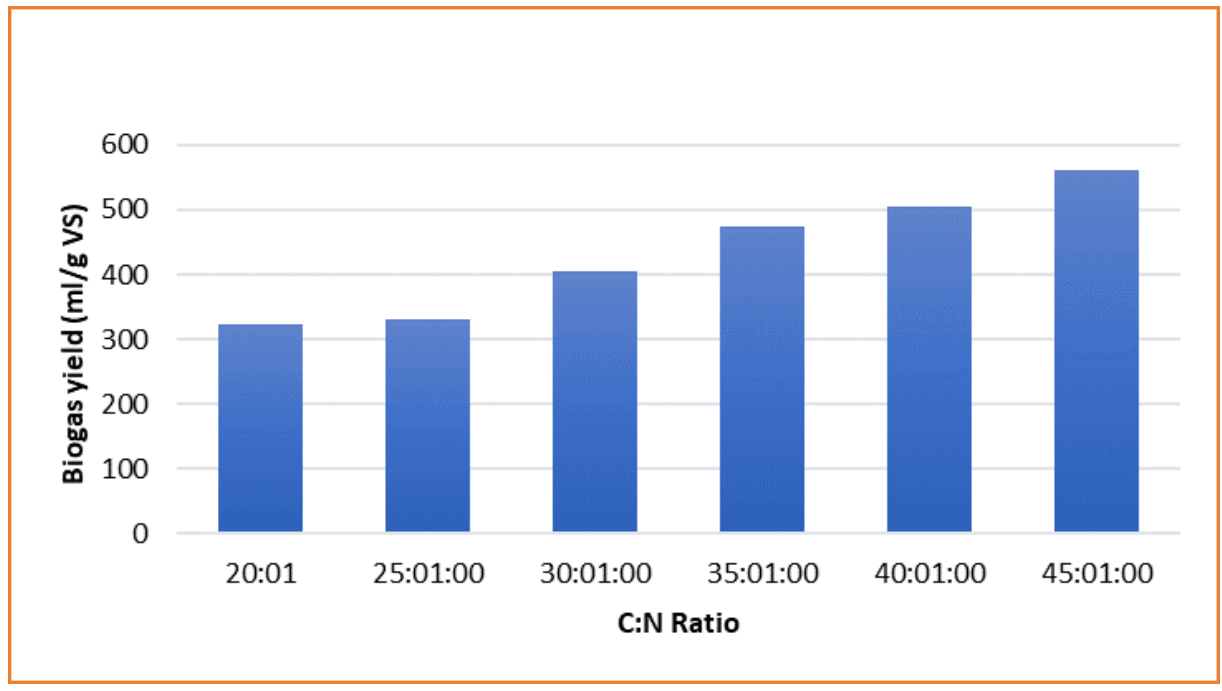

Fig, 6. Effect of Carbon-Nitrogen Ratio on Biogas Yield 
Ali Raza (et al.), Current status of microalgae to produce biogas through pretreatment of lignocellulosic waste in the era of 21-Century

\subsection{Carbon to Nitrogen Ratio (C: $N$ )}

Carbon to nitrogen ratio increase the complications for anaerobic digestion of microalgal biomass which indirectly affect the production of biogas [70]. High amount of nitrogen in the form of ammonia have inhibitory effect on anaerobic digestion, thus, nitrogen cause negative effect on biogas productivity indirectly [71] [50]. This problem can be solved by adding nutrients in the form of high carbon substrate for digestion that will reduce inhibitory effect of ammonia [71] as shown in Fig, 6.

\subsection{Ammonia-Nitrogen toxicity}

By hydrolysis of nitrogen containing compounds (Protein, urea, and Keratin), which are impregnated in algal cell cause ammonia- nitrogen toxicity. Thus, ammonianitrogen concentration is passively entered in the cell by inhibiting methane synthesizing enzymes. Due to movement of ammonianitrogen ions imbalance the potassium concentration and decreased the biogas productivity [17]. This problem can be solved by removing acetogenic, hydrolytic and methanogenic bacteria from microalgal substrate. By removing bacteria, biogas production and anaerobic digestion increased. Optimum concentration of ammonia-nitrogen is $3000 \mathrm{mg} / \mathrm{L}$ in a reactor above this figure may affect the productivity of biogas [71] as shown in Fig, 7.

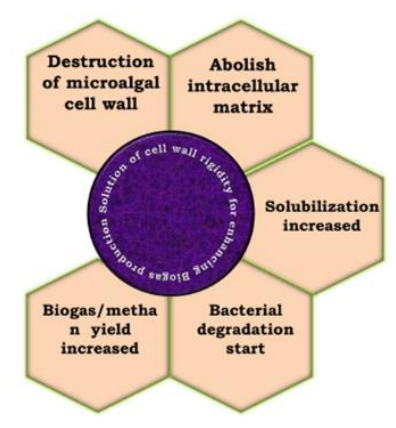

Fig, 7. Effect of Ammonia-Nitrogen toxicity on Biogas Yield

\subsection{Effect of Salinity}

(pp. 1 - 24)

Microalgae (Macrocystis pyrifera and Tetraselmis sp.) are cultivated in salinehabitat to protect the agricultural land. Lower alkaline earth metal is required for better anaerobic digestion in saline environment. Higher concentration of alkaline in soil will change the $\mathrm{pH}$ and cause toxicity for methanogenic bacteria. Higher salinity cause dehydration in bacterial cell due to higher osmotic pressure that cause inhibitory effect on anaerobic digestion. Sodium, aluminium and magnesium change the chemistry of saline environment that is toxic for anaerobic processing of algal biomass and indirectly effect the biogas production [40].

\subsection{Role of Sulfide:}

Microalgae in freshwater have less amount of sulfurated amino acid so during digestion $\mathrm{H} 2 \mathrm{~S}$ is produce in less amount. Marine water has measurable amount of oxidized sulphide compounds that act as electron acceptor for sulphide reducing bacteria to convert organic compounds into $\mathrm{H} 2 \mathrm{~S}$ that cause corrosion in apparatus (photobioreactor). Thus, this extra amount of H2S must be removed from apparatus which may affect less biogas productivity [40].

\section{Conclusion:}

Energy requisition now-a-days touched at higher level resulting in depletion of nonbiodegradable resources. That's why truncated energy production effects economic value of any industrial country to overcome this crisis by using algal lignocellulosic biomass undergoes anaerobic digestion. To contract high yield of bioenergy product over exploitation of agro-industrial wastes, wastewater and other enduring biomass that is unsurpassed way to improve economy or to marmalade the natural environment. 
Ali Raza (et al.), Current status of microalgae to produce biogas through pretreatment of lignocellulosic waste in the era of 21-Century

\section{List of Abbreviation}

HMF_ Hydro methyl furfurals MBWT_ Microalgal based wastewater treatment

\section{ACKNOWLEDGEMENTS}

Not applicable

\section{References}

[1] Khan, N.A. and H. el Dessouky, Prospect of biodiesel in Pakistan. Renewable and Sustainable Energy Reviews, 2009. 13(67): p. 1576-1583.

[2] Rupprecht, J., From systems biology to fuel--Chlamydomonas reinhardtii as a model for a systems biology approach to improve biohydrogen production. $\mathbf{J}$ Biotechnol, 2009. 142(1): p. 10-20.

[3] Schenk, P.M., et al., Second generation biofuels: high-efficiency microalgae for biodiesel production. Bioenergy research, 2008. 1(1): p. 20-43.

[4] Medipally, S.R., et al., Microalgae as sustainable renewable energy feedstock for biofuel production. Biomed Res Int, 2015. 2015: p. 519513.

[5] Parmar, A., et al., Cyanobacteria and microalgae: a positive prospect for biofuels. Bioresource technology, 2011. 102(22): p. 10163-10172.

[6] Demirbas, A., Biodiesel. 2008: Springer.

[7] Spolaore, P., et al., Commercial applications of microalgae. Journal of bioscience and bioengineering, 2006. 101(2): p. 87-96.

[8] Aresta, M., A. Dibenedetto, and G. Barberio, Utilization of macro-algae for enhanced $\mathrm{CO} 2$ fixation and biofuels production: Development of a computing software for an LCA study. Fuel processing technology, 2005. 86(14-15): p. 1679-1693.

[9] Baltrènas, P. and A. Misevičius, Biogas production experimental research using algae. Journal of Environmental Health Science and Engineering, 2015. 13(1): p. 18.

[10] Liu, Z.-Y., G.-C. Wang, and B.-C. Zhou, Effect of iron on growth and lipid accumulation in Chlorella vulgaris. Bioresource technology, 2008. 99(11): p. 4717-4722.

[11] Roberts, K.P., S. Heaven, and C.J. Banks, Comparative testing of energy (pp. 99 - 114)

yields from micro-algal biomass cultures processed via anaerobic digestion. Renewable Energy, 2016. 87: p. 744-753.

[12] Mudimu, O., et al., Biotechnological screening of microalgal and cyanobacterial strains for biogas production and antibacterial and antifungal effects. Metabolites, 2014. 4(2): p. 373-393.

[13]Zhu, C. and Y. Lee, Determination of biomass dry weight of marine microalgae. Journal of applied phycology, 1997. 9(2): p. 189-194.

[14]Mallick, N., et al., Progress and challenges in microalgal biodiesel production. Frontiers in microbiology, 2016. 7: p. 1019.

[15] Jankowska, E., A.K. Sahu, and P. Oleskowicz-Popiel, Biogas from microalgae: Review on microalgae's cultivation, harvesting and pretreatment for anaerobic digestion. Renewable and Sustainable Energy Reviews, 2017. 75: p. 692-709.

[16] Salerno, M., Y. Nurdogan, and T.J. Lundquist, Biogas production from algae biomass harvested at wastewater treatment ponds. 2009: American Society of Agricultural and Biological Engineers.

[17] Murphy, J.D., et al., A perspective on algal biogas. 2015: IEA Bioenergy.

[18] Manzoor, M., et al., Microalgal-bacterial consortium: a cost-effective approach of wastewater treatment in Pakistan. Punjab University Journal of Zoology, 2016. 31(2): p. 307-320.

[19] Mendez, L., et al., Chlorella vulgaris vs cyanobacterial biomasses: Comparison in terms of biomass productivity and biogas yield. Energy conversion and management, 2015. 92: p. 137-142.

[20] Marzano, C.M.A.D.S., et al., Biomethanation of the Marine Algae Tetraselmis. International Journal of Solar Energy, 1982. 1(4): p. 263-272.

[21] Kulkarni, M.G. and A.K. Dalai, Waste cooking oil an economical source for biodiesel: a review. Industrial \& engineering chemistry research, 2006. 45(9): p. 2901-2913.

[22] Quinn, J.C., et al., Microalgae to biofuels: life cycle impacts of methane production of anaerobically digested lipid extracted algae. Bioresource technology, 2014. 171: p. 37-43.

[23] Ravindran, R. and A.K. Jaiswal, A comprehensive review on pre-treatment strategy for lignocellulosic food industry 
Ali Raza (et al.), Current status of microalgae to produce biogas through pretreatment of lignocellulosic waste in the era of 21-Century (pp. 99 - 114)

waste: challenges and opportunities. Bioresource technology, 2016. 199: p. 92-102.

[24] Teghammar, A., Biogas Production from Lignocelluloses: Pretreatment, Substrate Characterization, Co-Digestion and Economic Evaluation. 2013, Chalmers Tekniska Högskola.

[25] Karlsson, H., et al., Ethanol production in biorefineries using lignocellulosic feedstock-GHG performance, energy balance and implications of life cycle calculation methodology. Journal of cleaner production, 2014. 83: p. 420-427.

[26] Miazek, K., et al., Effect of lignocellulose related compounds on microalgae growth and product biosynthesis: a review. Energies, 2014. 7(7): p. 4446-4481.

[27] Hu, Q., et al., Microalgal triacylglycerols as feedstocks for biofuel production: perspectives and advances. The plant journal, 2008. 54(4): p. 621-639.

[28] Taherzadeh, M.J. and K. Karimi, Pretreatment of lignocellulosic wastes to improve ethanol and biogas production: a review. International journal of molecular sciences, 2008. 9(9): p. 16211651.

[29] Cabral, J., E. Ferreira, and M. Mota, Book of abstracts of the 2nd Meeting of the Institute for Biotechnology and Bioengineering. 2010.

[30] Teghammar, A., et al., Techno-economic study of NMMO pretreatment and biogas production from forest residues. Applied Energy, 2014. 116: p. 125-133.

[31] Isikgor, F.H. and C.R. Becer, Lignocellulosic biomass: a sustainable platform for the production of bio-based chemicals and polymers. Polymer Chemistry, 2015. 6(25): p. 4497-4559.

[32] Vanholme, R., et al., Lignin biosynthesis and structure. Plant physiology, 2010. 153(3): p. 895-905.

[33] Qin, C., K. Clarke, and K. Li, Interactive forces between lignin and cellulase as determined by atomic force microscopy. Biotechnology for biofuels, 2014. 7(1): p. 65.

[34] González-Fernández, C., et al., Effect of organic loading rate on anaerobic digestion of thermally pretreated Scenedesmus sp. biomass. Bioresource technology, 2013. 129: p. 219-223.

[35] Ahmad, S., et al., Prospects for pretreatment methods of lignocellulosic waste biomass for biogas enhancement: opportunities and challenges. Biofuel 20. htt p s. doi. org/10.1080/1759, 2017. 7269(2017): p. 1378.

[36] Howard, R., et al., Lignocellulose biotechnology: issues of bioconversion and enzyme production. African Journal of biotechnology, 2003. 2(12): p. 602619.

[37] Ahmad, S., et al., Prospects for pretreatment methods of lignocellulosic waste biomass for biogas enhancement: opportunities and challenges. Biofuels, 2018. 9(5): p. 575-594.

[38]Ziemiński, K., I. Romanowska, and M. Kowalska, Enzymatic pretreatment of lignocellulosic wastes to improve biogas production. Waste management, 2012. 32(6): p. 1131-1137.

[39] Kong, Q.-X., et al., Culture of microalgae Chlamydomonas reinhardtii in wastewater for biomass feedstock production. Applied biochemistry and Biotechnology, 2010. 160(1): p. 9.

[40] Sharma, S., Algae Energy: A Perspective on Algae as a Biogas source in Nordic Climate. 2017.

[41] Spolaore, P., et al., Commercial applications of microalgae. $\mathrm{J}$ Biosci Bioeng, 2006. 101(2): p. 87-96.

[42] Varol, A. and A. Ugurlu, Biogas production from microalgae (Spirulina platensis) in a two stage anaerobic system. Waste and biomass valorization, 2016. 7(1): p. 193-200.

[43] Benhelal, E., et al., "ACEME": Synthesis and characterization of reactive silica residues from two stage mineral carbonation Process. Environmental Progress \& Sustainable Energy, 2019. 38(3): p. e13066.

[44]Li, Y., et al., Characterization of a microalga Chlorella sp. well adapted to highly concentrated municipal wastewater for nutrient removal and biodiesel production. Bioresource technology, 2011. 102(8): p. 5138-5144.

[45] Xin, L., H. Hong-Ying, and Y. Jia, Lipid accumulation and nutrient removal properties of a newly isolated freshwater microalga, Scenedesmus sp. LX1, growing in secondary effluent. New biotechnology, 2010. 27(1): p. 59-63.

[46] Mussgnug, J.H., et al., Microalgae as substrates for fermentative biogas production in a combined biorefinery concept. Journal of biotechnology, 2010. 150(1): p. 51-56. 
Ali Raza (et al.), Current status of microalgae to produce biogas through pretreatment of lignocellulosic waste in the era of 21-Century

[47] Batista, A.P., L. Gouveia, and I.P.R.

Marques. Scenedesmus obliquus: biogas production from residues of biodiesel/bioethanol extraction processes [Resumo]. in 2nd International Conference on Algal Biorefinery: A potential source of food, feed, biochemicals, biofuels and biofertilizers. 2014.

[48] Órpez, R., et al., Growth of the microalga Botryococcus braunii in secondarily treated sewage. Desalination, 2009. 246(1-3): p. 625-630.

[49] Unpaprom, Y., et al., Cultivation of microalga Botryococcus braunii using red Nile tilapia effluent medium for biogas production. Journal of Ecology and Environmental Sciences, 2015. 3(2): p. 58-65.

[50]Neumann, P., et al., Anaerobic codigestion of lipid-spent microalgae with waste activated sludge and glycerol in batch mode. International Biodeterioration \& Biodegradation, 2015. 100: p. 85-88.

[51] Varel, V., T. Chen, and A. Hashimoto, Thermophilic and mesophilic methane production from anaerobic degradation of the cyanobacterium Spirulina maxima. Resources, conservation and recycling, 1988. 1(1): p. 19-26.

[52] Bohutskyi, P., M.J. Betenbaugh, and E.J. Bouwer, The effects of alternative pretreatment strategies on anaerobic digestion and methane production from different algal strains. Bioresource technology, 2014. 155: p. 366-372.

[53] Newsted, J.L., Effect of light, temperature, and $\mathrm{pH}$ on the accumulation of phenol by Selenastrum capricornutum, a green alga. Ecotoxicology and environmental safety, 2004. 59(2): p. 237-243.

[54] Munir, N., et al., Optimization of growth conditions of different algal strains and determination of their lipid contents. J Anim Plant Sci, 2015. 25(2): p. 546-553.

[55] Converti, A., et al., Effect of temperature and nitrogen concentration on the growth and lipid content of Nannochloropsis oculata and Chlorella vulgaris for biodiesel production. Chemical Engineering and Processing: Process Intensification, 2009. 48(6): p. 11461151 .

[56] Konopka, A. and T.D. Brock, Effect of temperature on blue-green algae (cyanobacteria) in Lake Mendota. Appl.

(pp. 99 - 114) Environ. Microbiol., 1978. 36(4): p. 572576.

[57] Golueke, C.G., W.J. Oswald, and H.B. Gotaas, Anaerobic digestion of algae. Applied microbiology, 1957. 5(1): p. 47.

[58] Bajhaiya, A., et al., Algal biodiesel The next generation biofuel for India. Asian J. Exp. Biol. Sci, 2010. 4: p. 728-739.

[59] Cerón Garcí, M.C., et al., Mixotrophic growth of Phaeodactylum tricornutum on glycerol: growth rate and fatty acid profile. Journal of Applied Phycology, 2000. 12(3): p. 239-248.

[60] Janssen, M., et al., Specific growth rate of Chlamydomonas reinhardtii and Chlorella sorokiniana under medium duration light/dark cycles: 13-87 s. Journal of biotechnology, 1999. 70(1-3): p. 323-333.

[61]Bhatnagar, A., et al., Chlorella minutissima - a promising fuel alga for cultivation in municipal wastewaters. Applied biochemistry and biotechnology, 2010. 161(1-8): p. 523536.

[62] Chen, F., High cell density culture of microalgae in heterotrophic growth. Trends in biotechnology, 1996. 14(11): $\mathrm{p}$. 421-426.

[63] Hasunuma, T., et al., Development of a GIN11/FRT-based multiple-gene integration technique affording inhibitortolerant, hemicellulolytic, xyloseutilizing abilities to industrial Saccharomyces cerevisiaestrains for ethanol production from undetoxified lignocellulosic hemicelluloses. Microbial cell factories, 2014. 13(1): p. 145.

[64] Wi, S.G., et al., Lignocellulose conversion for biofuel: a new pretreatment greatly improves downstream biocatalytic hydrolysis of various lignocellulosic materials. Biotechnology for biofuels, 2015. 8(1): p. 228 .

[65] Sakai, S., et al., Effect of lignocellulosederived inhibitors on growth of and ethanol production by growth-arrested Corynebacterium glutamicum R. Appl. Environ. Microbiol., 2007. 73(7): p. 2349-2353.

[66] Jönsson, L.J., B. Alriksson, and N.-O. Nilvebrant, Bioconversion of lignocellulose: inhibitors and detoxification. Biotechnology for biofuels, 2013. 6(1): p. 16.

[67] Karlsson, A., et al., Improvement of the Biogas Production Process: Explorative 
Ali Raza (et al.), Current status of microalgae to produce biogas through pretreatment of lignocellulosic waste in the era of 21-Century

project (EP1). 2014, Linköping University Electronic Press.

[68] Makarevičienè, V., et al., Performance and emission characteristics of diesel fuel containing microalgae oil methyl esters. Fuel, 2014. 120: p. 233-239.

[69] Prajapati, S.K., et al., Enhanced methane production from algal biomass through short duration enzymatic pretreatment and codigestion with carbon rich waste. RSC Advances, 2015. 5(82): p. 6717567183.

[70] Hossain, A.S., et al., Biodiesel fuel production from algae as renewable energy. American journal of biochemistry and biotechnology, 2008. 4(3): p. 250-254.

[71] Ward, A., D. Lewis, and F. Green, Anaerobic digestion of algae biomass: a review. Algal Research, 2014. 5: p. 204214. 
